"With its extensive international coverage and institutional detail, it should become the standard work on the structure of the asset management industry."

- Richard Brealey, London

Business School

406 pp. $\$ 47.95$

\section{The Economics of Risk and Time}

Christian Gollier

“Gollier's treatise on risk and time will be the bible for future finance theory and practice. Get your copy; read and reread. Keep ahead of the competitive mob."

- Paul A. Samuelson, MIT

520 pp., 54 illus. $\$ 54.95$ now in paperback

Comparing

Financial

Systems

Franklin Allen and Douglas Gale

"This excellent book is a must-read for anyone interested in an in-depth understanding of how financial systems have evolved in different countries." - Anjan Thakor, University of Michigan Business School

519 pp., 32 illus. \$29.95 paper

http://mitpress.mit.edu

To order call 800-356-0343 (US \& Canada) or 617625-8569. Prices subject to change without notice. 


\section{Forthcoming Articles}

The following papers have been accepted for publication in future issues:

Does Conditioning Information Matter in Estimating Continuous Time Interest Rate Diffusions?

Abhay H. Abhyankar and Devraj Basu

Economic News and Bond Prices: Evidence from the U.S. Treasury Market Pierluigi Balduzzi, Edwin J. Elton, and T. Clifton Green

Managerial Ownership, Incentive Contracting and the Use of Zero-Cost Collars and Equity Swaps by Corporate Insiders

Carr Bettis, John M. Bizjak, and Michael L. Lemmon

Takeover Defenses and Dilution: A Welfare Analysis

Atreya Chakraborty and Richard Arnott

Long-Run Performance and Insider Trading in Completed and Canceled Seasoned Equity Offerings Jonathan Clarke, Craig G. Dunbar, and Kathleen M. Kahle

Why Do Option Introductions Depress Stock Prices? A Study of Diminishing Short-Sale Constraints

Bartley R. Danielsen and Sorin M. Sorescu

Day Trading International Mutual Funds: Evidence and Policy Solutions William N. Goetzmann, Zoran Ivković, and Geert Rouwenhorst

Stock Market Volatility in a Heterogeneous Information Economy

Bruce D. Grundy and Youngsoo Kim

Tick Size, Bid-Ask Spreads and Market Structure

Roger D. Huang and Hans R. Stoll

Performance Changes following Top Management Turnover: Evidence from Open-End Mututal Funds

Ajay Khorana

Firm Internationalization and the Cost of Debt Financing: Evidence from NonProvisional Publicly Traded Debt

David M. Reeb, Sattar A. Mansi, and John M. Allee

The Decline of Inflation and the Bull Market of 1982 to 1999

Jay R. Ritter and Richard S. Warr

Trading Volume and Information Revelation in Stock Markets Matti Suominen 
opportunities for conference participants. You may submit your proposal to arrange a special session by writing to the Program Chair.

Publication. A set of papers presented at the meeting will be selected by the 2002 Program Chair and will be published, with author/s consent, in a regular issue of the European Financial Management journal, in cooperation with the Managing Editor. All submitted papers must be accompanied by an abstract of at least 250 words, but no more than 400 words.

Submission. The first page of the paper should contain the title, name of the author(s), abstract, complete address, telephone, fax numbers, and e-mail addresses. If there are multiple authors, please indicate which author will attend and which will present the paper. Also, indicate in your cover letter whether you would be willing to serve as a session chair and / or discussant.

Deadline. The deadline for papers and proposals is January 15, 2002. Authors will be notified by March 14, 2002. If your paper is accepted, you must send the final version of your paper to the discussant and session chair by May 20, 2002. Please send, preferably by courier (i.e., FedEx, DHL, etc.), five (5) copies of your paper along with a disk in MSWord or PDF format:

\author{
Dr. Constantine Thanassoulas \\ Program Chair, 2002 Meeting \\ Chief Operating Officer \\ Sanwa International Plc \\ City Place House \\ 55 Basinghall Street \\ London EC2V 5DJ UK \\ Tel:+442073300302 Fax:+442073300375
}

E-mail: CThanassoulas@ sanwaint.com URL: http://www.efmaefm.org 


\section{JFQA Style Requirements}

Electronic submissions in PDF files are welcome or laser-quality manuscripts may be submitted in quadruplicate on $8.5^{\prime \prime} \times 11^{\prime \prime}$ paper. The cover page must show title, author name(s) and affiliation(s), and work phone number(s). The first page of text should include the title and a one-paragraph abstract of no more than 100 words. Manuscripts must be double-spaced on one side of the page. All sections of the paper, beginning with the introduction and ending with a conclusion or summary, must be numbered with Roman numerals. Subsection headings must be lettered $A, B, C$, etc.

The manuscript should explain its relation to other research in the field, especially recently published material. References cited in the text should be noted by the last name(s) of the author(s) followed by the publication year enclosed in parentheses without punctuation: Smith (1988). When a particular page, section, or equation is referred to, the reference also should be placed within parentheses: (Smith and Jones (1988), p. 222), (Green (1988a), eq. 3).

Lengthy mathematical proofs and extensive tables should be placed in an appendix or omitted from the manuscript entirely. In the latter case, the author may indicate in a footnote that proofs or tables are available on request. The author should make every effort to explain the meaning of mathematical proofs.

The author should check the manuscript for clarity, grammar, spelling, and punctuation to minimize editorial changes and the necessity of extensive corrections at the proof stage. All abbreviations must be defined.

Equations. All but very short mathematical expressions should be displayed on a separate line and centered. Important displayed equations must be identified by consecutive Arabic numerals in parentheses on the left. Expressions should be aligned and subscripts and superscripts clearly marked to avoid confusion.

Tables. Each table must be titled and numbered consecutively with Arabic numerals. Please check the text to make sure there is a reference to each table. General footnotes should be marked a, b, c, etc., for specific footnotes. Asterisks ${ }^{*}$ or ${ }^{* *}$ indicate significance at the $5 \%$ and $1 \%$ levels, respectively. The author should check tables to be sure that totals are correct and that the title, column headings, and footnotes clearly explain the content of the table. If tables are on separate pages at the end of the article, indicate approximate placement within the text.

Figures. Figures must be titled and numbered consecutively with Arabic numerals. Captions should present sufficient information to describe the purpose of the figure. Figures for accepted manuscripts must be of professional quality and ready for reproduction.

Footnotes. Footnotes must be double-spaced. Footnotes must not be used for the purpose of citation. Footnotes with extensive content should be avoided.

References. All works cited in the text must be alphabetically arranged in a double-spaced list at the end of the manuscript. Examples:

Brown, S., and J. Warner. "Using Daily Stock Returns: The Case of Event Studies." Journal of Financial Economics, 14 (1985), 1-31.

Ross, S. A. "Return Risk and Arbitrage." In Risk and Return in Finance, Vol. I, I. Friend and J. L. Bicksler, eds. Cambridge, MA: Ballinger (1977). 


\section{IF@ Journal of Financial and Quantitative Analysis Subscription Information}

The Journal of Financial and Quantitative Analysis (JFQA) is published quarterly in March, June, September, and December by the School of Business Administration at the University of Washington in Seattle, Washington, U.S.A. Topics include corporate finance, investments, capital and security markets, and quantitative methods of particular relevance to financial researchers. With a circulation of 3200 libraries, firms, and individuals in 70 nations, the JFQA serves an international community of sophisticated finance scholars-academics and practitioners alike. The JFQA prints 10 to $12 \%$ of the more than 400 unsolicited manuscripts submitted annually. An intensive blind review process and exacting editorial standards contribute to the JFQA's reputation as a top finance journal.

Payment in advance is required. Checks or money orders must be payable to the JFQA in U.S. dollars for deposit in a U.S. bank. Subscriptions start with the next available issue unless otherwise requested. Upon request, electronic subscriptions are available in PDF files. Claims for missing issues must be made within six months of the publication date.

To inquire about permission to reprint or the availability of specific back issues (at a cost of $\$ 15$ per copy), contact the JFQA office.

$\begin{array}{lccc} & \text { U.S. } & \text { International } & \text { Amount } \\ \text { Library or Firm } & \$ 95 & \$ 100 & \\ \text { Individual } & \$ 45 & \$ 50 & \\ \text { Student (with verification) } & \$ 25 & \$ 30 & - \\ & & & \\ & \text { International Airmail } & \$ 30 & \\ & & \text { Total Amount Paid } & \end{array}$

Please start subscription with the $\square$ March $\square$ June $\square$ Sept $\square$ Dec issue.

Name

Company

Address

City $\_$State
Country E-mail $\_$ZIP
Phone
Payment made by: $\square$ Check $\square$ VISA $\square$ MasterCard $\square$ American Express
Account No.
Cardholder's Name
Signature

Journal of Financial and Quantitative Analysis

University of Washington

School of Business Administration

115 Lewis

Box 353200

Seattle, WA 98195-3200 U.S.A.

Phone: (206) 543-4598

Fax: (206) 616-1894

Federal Identification No.: 91-6001537

ISSN: 0022-1090

Office Use Only

Chk \#

CT

Iss

E-mail: jfqa@jfqa.org URL: http://www.jfqa.org 